\title{
8. On a new Gecko from Penang.
} By G. A. Boulenger, F.R.S.

[Received June 16, 1896.]

\section{(Plate XXXVI.)}

Among some Reptiles and Batrachians collected on Penang hill (at 2200 feet altitude) by Mr. Stanley Flower, and presented by bim to the Natural History Museum, there was a new Gecko of particular interest. At a first glance it appears to be a Plychozoon, that curious form of parachute-bearing Geckos of which we now know two species from South-eastern Asia, viz., P. homalocephalum, Crev., and P. horsfieldi, Gray. But this resemblance is merely a case of convergence, for whilst Ptychozoon is a modified form of Geclco, the new lizard is clearly derived from Hemidactylus. The gap between the species referred to Gecko and those on which Ptychozoon is based is so considerable, that the latter genus has been universally accepted by modern herpetologists. But in the present case the matter is not quite so simple; for we have long been acquainted with a species of Hemidactylus,-H. platyurus, Schn.,- which, by the presence of a well-developed fold along the side, foreshadows the development of the parachute of Plychozoon; however, the scaling on these membranes does not show any modification, and therefore $I$ have thought it fit to found a new genus for the species described below, which differs in the brick-like enlarged scales covering the side-membranes, as well as in the greater development of these membranes and the fuller web between the digits. If Ptychozoon deserves to stand as distinct from Gecko, it would be illogical not to allow the same rank to the new Penang Lizard. I therefore propose to name it Mimetozoon floweri.

\section{Mimetozoon, gen. nov.}

Digits extensively webbed, strongly dilated, with two rows of lamellæ beneath; the two distal phalanges compressed and slender, rising from within the extremity of the dilated portion; all the digits clawed. Limbs and sides of head, body, and tail with muchdeveloped dermal expansions. Upper surfaces covered with juxtaposed granular scales and tubercles, the parachute-membrane covered above with inbricate tetragonal scales arranged like bricks. Pupil vertical.

\section{Mimetozoon floweri, sp. nov. (Plate XXXVI.)}

Head slightly distinct from neck; snout obtusely pointed, much longer than the distance between the eye and the ear-opening, once and a half the diameter of the orbit; forehead concave; ear-opening oval, horizontal. Body and limbs much depressed; digits short, two-thirds webbed, inner short; five lamellm under

Proc. Zool. Soo.-1896, No. L. 
the inner digit, eight or nine under the fourth ; limbs with dermal folds, the largest extending from the vent to the fifth toe. Tail much depressed, bordered on each side by a broad, entire, dermal fold with fringed edge. Rostral quadrangular, broader than deep; nostril pierced between the rostral and four scales; 12 upper and 10 lower labials; symphysial triangular; two pairs of chin-shields, the median forming a suture behind the symphysial. Head, back, and limbs covered with small granules, largest on the snout; occiput and back with numerous small, round, smooth tubercles; ventral scales small, cycloid, imbricate, smooth. Tail covered with small granular scales, the muscular portion with transverse rows of small smooth tubercles above, with a series of transverse shields beneath. Grey above, speckled with brown, with quadrangular dark spots disposed in pairs along the back, connected by brownish bands and wavy transverse lines, and confluent into cross-bars on the tail; a dark streak on each side of the head, passing through the eye; pale yellow beneath, speckled with blackish on the sides, the muscular portion of the tail coral-red. "Iris golden brown."

\begin{tabular}{|c|c|c|}
\hline T'otal length & millim. & Fore limb \\
\hline Head ........ & 16 & Hind limb \\
\hline Width of bead & 9 & Tail .... \\
\hline Body ....... & 43 & \\
\hline
\end{tabular}

The single specimen is a female.

\section{Notes on a Recent Zoological Expedition on the Lower Amazon. By E. E. Austen, Zoological Department, British Museum.}

[Received June 16, 1896.]

In the antumn of last year Mr. Alexander Siemens, of the firm of Messirs. Siemens, Bros. \& Co., Limited, of Woulwich, being about to proceed to the Amazon in command of an expedition for the purpose of laying a telegraph-cable from Pará to Manaos, and having been much interested by the perusal of the well-known works of Bates and Wallace on the fauna of this particular region of the South-American continent, thought that the expedition would afford an excellent opportunity of increasing the national collections. Mr. Siemens accordingly made a most public-spirited offer to the Trustees of the British Museum to the effect that, should they desire to avail themselves of the opportunity, he would be pleased to take on board his ship, the cable s.s. 'Faraday,' a nember of the Museum staff in order to make collections at the various localities on the river with which telegraphic connection would have to be effected. Needless to say, the Trustees accepted the offer in the spirit in which it was made, and through the 


\section{$2 \mathrm{BHL}$ Biodiversity Heritage Library}

Boulenger, George-Albert. 1896. "8. On a new Gecko from Penang." Proceedings of the Zoological Society of London 1896, 767-768.

https://doi.org/10.1111/j.1096-3642.1896.tb03077.x.

View This Item Online: $\underline{\text { https://www.biodiversitylibrary.org/item/97658 }}$

DOI: https://doi.org/10.1111/j.1096-3642.1896.tb03077.x

Permalink: https://www.biodiversitylibrary.org/partpdf/72752

\section{Holding Institution}

Smithsonian Libraries

\section{Sponsored by}

Biodiversity Heritage Library

\section{Copyright \& Reuse}

Copyright Status: Public domain. The BHL considers that this work is no longer under copyright protection.

This document was created from content at the Biodiversity Heritage Library, the world's largest open access digital library for biodiversity literature and archives. Visit BHL at https://www.biodiversitylibrary.org. 